\title{
Adjuvant therapy of chronic gastroduodenitis in children with dysplasia of connective tissue
}

\author{
O. M. Mukvich ${ }^{1}$, D. S. Yankovskyi ${ }^{3}$, V. P. Shirobokov ${ }^{2}$, H. S. Dyment ${ }^{3}$, O. V. Lavrenchuk ${ }^{4}$ \\ ${ }^{1}$ Institute of Pediatrics, Obstetrics and Gynecology of NAMS Ukraine, Kyiv, ${ }^{2}$ O. O. Bogomolets National Medical University, Kyiv, Ukraine, \\ ${ }^{3}$ Scientific Production Company "OD Prolisok", Kyiv, Ukraine, " Public Non-Profit Enterprise "Center of Primary Medical and Sanitary Health № 1", \\ Shevchenko District, Kyiv, Ukraine
}

\begin{abstract}
Chronic gastroduodenitis (CGD) hold one of main places among leading diseases of gastro-intestinal tract (GIT) in childhood. A special category is children who have CGD against the background of connective tissue (CT) dysplasia (DCT). CGD in such children is characterized by early appearance, aggressive, gradient course with frequent acute conditions and recurrences with evident symptoms of nonspecific intoxication manifestations. Defect of collagen synthesis leads to pronounced morphological changes of proximal GIT mucous membrane (MM) and decline in its cytoptotecive abilities. Challenges related to the qualitative and quantitative local ecosystem changes can aggravate immune and metabolic local processes and enhance the destruction of proximal GIT mucous membrane. Aforesaid defines the need to include multiprobiotics into the treatment schemes of patient with CGD, associated with congenital fibrogenesis disorders, as adjuvant therapy with complex therapeutic action; they positively influence the $\mathrm{CT}$ metabolism, improve reparative processes in MM, normalize immune processes and maintain composition and functions of physiological microbiota.
\end{abstract}

Purposes - improvement of CGD treatment efficiency in children with DCT through inclusion of the multiprobiotic Symbiter ${ }^{\circledR}$ forte-M into the treatment schemes.

Materials and methods. There were examined 33 children with CGD on the background of DCT and 32 healthy children (control) from 11 to 17 years old. The state of the mucous barrier was estimated by certain mucin constituents (fucose, glycosaminoglycans, sialic acids) assessing, antimicrobial peptides (ß2-defencins), non-specific humoral factors of the local immunity (immunoglobulins, lysozyme) in mucous secretions (saliva, coprofiltrate (CF)) before and after probiotic therapy.

Results. Increased concentrations of $\beta_{2}$-defencins $\left(p_{\text {saliva }}=0.03, p_{C F}=0.03\right)$, sialic acids $(P=0.04)$ and lysozyme $(P=0.01)$ and decreased of fucose level $(P=0.03)$ in mucous secretions under application of multicomponent probiotic preparation were observed.

Conclusions. In children with DCT and CGD development, mucins, forming protective homeostatic barrier between residential microbiota and basic immune intestinal cells, contain in their composition increased quantity of fucose-containing glycoproteins and low amount of sialic acids; this influences microbiota and activity of cytoprotective and reparative processes in MM. Inclusion of the multiprobiotic Symbiter ${ }^{\circledR}$ forte-M into the standard treatment scheme leads to the normalization of some mucus glycoproteins and non-specific humoral local immunity factors. Due to its complex composition with high probiotic and immunomodulatory properties and natural mineral gel (smectite) inclusion, the multiprobiotic improves cytoprotective and reparative properties of GIT mucous membrane and reduces the likelihood of severe destructive processes in children with CGD and DCT development.

\section{Ад'ювантна терапія хронічних гастродуоденітів у дітей із диспиазією сполучної тканини}

\section{О. М. Муквіч, А. С. Янковський, В.П.Широбоков, Г. С. Аимент, О. В. Аавренчук}

Хронічний гастродуоденіт (ХГД) посідає одне з провідних місць серед захворювань шлунково-кишкового тракту (ШКТ) у дітей. Особлива категорія - діти, в яких ХГД формується на тлі дисплазії сполучної тканини (ДСТ). ХГД у них характеризується раннім дебютом, агресивним, прогредієнтним перебігом із частими загостреннями, рецидивами 3 вираженими проявами симптомів неспецифічної інтоксикації. Детермінований дефект синтезу колагену зумовлює виражені морфологічні зміни слизової оболонки (СО) верхніх відділів ШКТ зі зниженням її цитопротекторних властивостей. Якісні та кількісні зміни місцевої екосистеми, що неодмінно виникають при цьому, поглиблюють імунні й метаболічні локальні процеси, посилюють деструкцію СО верхніх відділів ШКТ. Це визначає необхідність включення у схеми лікування пацієнтів із ХГД, асоційованим із вродженими порушеннями фіброгенезу, мультипробіотиків як ад'ювантної терапії з комплексною терапевтичною дією: позитивним впливом на метаболізм сполучної тканини (CT), поліпшенням репаративних процесів у СО, нормалізацією імунних процесів, підтримкою складу та функцій фізіологічної мікробіоти.

Мета роботи - підвищення ефективності лікування ХГД у дітей із ДСТ шляхом включення у схему лікування комплексного мультипробіотика Сімбітер ${ }^{\circledR}$ форте-М.

Матеріали та методи. Обстежили 33 дитини з ХГД на тлі ДСТ і 32 здорові дитини віком 11-17 років. Стан слизового бар'єра оцінювали на основі визначення окремих складових муцинів (фукози, глюкозаміногліканів, сіалових кислот), антимікробних пептидів (ß2-дефензинів), неспецифічних гуморальних факторів локального імунітету (імуноглобулінів, лізоциму) в мукозальних секретах (слині, копрофрільтратах) до та після пробіотикотерапії.

Результати. При застосуванні мультикомпонентного пробіотичного препарату в мукозальних секретах підвищуються концентрації ß2-дефензинів $\left(p_{\text {слина }}=0,03, p_{\kappa ф}=0,03\right)$, сіалових кислот $(p=0,04)$, лізоциму $(p=0,01)$ та знижується рівень фрукози $(p=0,03)$.
Key words: children, hypertrophic gastroduodenitis, connective tissue diseases, treatment, probiotics.

\section{Zaporozhye} medical journal 2018; 20 (2), 291-296

DOI:

10.14739/2310-1210 2018.2.125584

\section{E-mail:}

ov.lavrenchuk@ gmail.com 
Висновки. При розвитку ХГД у дітей із ДСТ муцини, котрі утворюють захисний гомеостатичний бар'єр між резидентною мікробіотою та базовими імунними клітинами кишечника, містять у своєму складі підвищену кількість фукозовмісних глікопротеїнів і характеризуються низьким вмістом сіалових кислот, що визначає особливості фрормування мікробіоти та активність цитопротективних і репаративних процесів у СО. Включення мультипробіотика Сімбітер ${ }^{\circledR}$ форте-М у стандартну схему лікування призводить до нормалізації окремих складових глікопротеїнів слизу та факторів неспецифрічного гуморального локального імунітету. Завдяки комплексному складу з включенням гелю природного мінералу (смектиту), високим пробіотичним і імуномодулювальними властивостями мультипробіотик поліпшує цитопротективні та репаративні властивості слизової оболонки ШКТ і зменшує вірогідність розвитку тяжких форм деструктивних процесів при ХГД у дітей із ДСТ.

Ключевые слова:

Аети,

гастродуоденит, Аиспиазия

соединительной ткани, мечение, мультипробиотик.

Запорожский медицинский журнал. - 2018. -

T. 20, № 2(107). C. 291-296

\title{
Адъювантная терапия хронических гастродуоденитов у детей с диспказией соединительной ткани
}

\author{
Е. Н. Муквич, А. С. Янковский, В. П. Широбоков, Г. С. Аымент, О. В. Аавренчук
}

Хронический гастродуоденит (ХГД) занимает одно из ведущих мест среди заболеваний желудочно-кишечного тракта (ЖКТ) у детей. Особую категорию составляют дети, у которых ХГД формируется на фоне дисплазии соединительной ткани (ДСТ). ХГД у них характеризуется ранним дебютом, агрессивным, прогредиентным течением с частыми обострениями, рецидивами с выраженными проявлениями симптомов неспецифической интоксикации. Детерминированный дефект синтеза коллагена обусловливает выраженные морфологические изменения слизистой оболочки (CO) верхних отделов ЖКТ со снижением ее цитопротекторных свойств. Качественные и количественные изменения местной экосистемы, которые непременно возникают при этом, усугубляют иммунные и метаболические локальные процессы, усиливают деструкцию СО верхних отделов ЖКТ. Указанное определяет необходимость включения в схемы лечения пациентов с ХГД, ассоциированные с врожденными нарушениями фиброгенеза, мультипробиотиков в качестве адъювантной терапии с комплексным терапевтическим действием: положительным влиянием на метаболизм соединительной ткани (СТ), улучшением репаративных процессов в $\mathrm{CO}$, нормализацией иммунных процессов, поддержанием состава и функций физиологической микробиоты.

Цель работы - повышение эффективности лечения ХГД у детей с ДСТ путем включения в схемы лечения комплексного мультипробиотика Симбитер ${ }^{\circledR}$ форте-М.

Материалы и методы. Обследовали 33 ребенка с ХГД на фоне ДСТ и 32 здоровых ребенка 11-17 лет. Состояние слизистого барьера оценивали на основании определения отдельных составляющих муцинов (фукозы, глюкозаминогликанов, сиаловых кислот), антимикробных пептидов (ß2-дефензинов), неспецифических гуморальных факторов местного иммунитета (иммуноглобулинов, лизоцима) в мукозальных секретах (слюне, копрофильтратах) до и после пробиотикотерапии.

Результаты. Установлено, что при применении мультикомпонентного пробиотического препарата в мукозальных секретах повышаются концентрации ß2-десензинов ( $\left.p_{\text {слюна }}=0,03, p_{\kappa ф}=0,03\right)$, сиаловых кислот $(p=0,04)$, лизоцима $(p=0,01)$ и снижается уровень фукозы $(p=0,03)$.

Выводы. При развитии ХГД у детей с ДСТ муцины, которые образуют защитный гомеостатический барьер между резидентной микробиотой и базовыми иммунными клетками кишечника, содержат повышенное количество фукозосодержащих гликопротеинов и характеризуются низким содержанием сиаловых кислот, что определяет особенности формирования микробиоты и активность цитопротективных и репаративных процессов в СО. Включение мультипробиотика Симбитер ${ }^{\circledast}$ форте-М в стандартные схемы лечения приводит к нормализации отдельных составляющих гликопротеина слизи и факторов неспецифического гуморального местного иммунитета. Благодаря комплексному составу с включением геля природного минерала (смектит), высоким пробиотическим и иммуномодулирующим свойствам, мультипробиотик улучшает цитопротективные и репаративные свойства слизистой оболочки ЖКТ и уменьшает вероятность развития тяжелых форм деструктивных процессов при ХГД у детей с ДСТ.

\section{Introduction}

Chronic gastroduodenitis (CGD) is among leading diseases of the gastro-intestinal tract (GIT) in childhood [1]. Last year investigations have confirmed the multifactor genesis of this pathology, frequent recurrences with early chronization of the processes and insufficient effectiveness of the preventive and curative measures in use. Children are a special category with CGD development at the background of inherited CT disorganization. The number of such children progressively increases worldwide due to difficult environments, small doses of irradiation prolonged action, pregnancy pathological course and change in diet quality [2]. The CGD course in children at the background of CT dysplasia (DCT) is characterized by early appearance, gradual rising with frequent acute conditions, recurrences with marked manifestations of nonspecific intoxication symptoms and tendency to GIT proximal parts destructive lesion development [3].

Genetic defects of collagen synthesis and the cause of DCT pathogenesis lead to immunological, metabolic and morphologic changes of pre-epithelial mucus layers of proximal GIT [4]. Local microbe ecosystem quantitative and qualitative changes, resulting from that, aggravate immune and metabolic local processes and strengthen destruction of GIT proximal segments [5,6].

Maintaining and correction of physiologic microbiota play a key role in the formation of immune system functions, resistibility to infections and retaining of homeostasis and many complex metabolic processes of the human organism [7]. Mentioned above implies that the adjuvant therapy with complex therapeutic action should be included into treatment regimens for patients with chronic inflammatory processes in proximal GIT segments, associated with 
inherited fibrogenesis disorders. Such therapy may positively influence the CT metabolism, reparative processes in CT of GIT, immune processes normalization, as well as the composition and functions of physiologic microbiota.

Multiprobiotic Symbiter ${ }^{\circledR}$ forte-M contains a biomass of symbiotic probiotic microorganisms with $\mathrm{KFU} / \mathrm{g}$ : lactobacilli $-1.0 \times 10^{9}$, bifidobacteria $-1.0 \times 10^{9}$, lactic acid streptococci-1.0 $1.10^{8}$, propionic acid bacteria -1.0 $\times 10^{8}$, acetic-acid bacteria $-1.0 \times 10^{5}$. Besides, it additionally contains bentonite gel, smectite. Smectite is a sorbent based on the natural clay poly-mineral with the lattice of silicon, oxygen, and aluminium that contains admixtures of many mineral elements, which may easy enter into exchange reactions with chemical substances in GIT and supplement their deficiency in the organism [8]. Due to the highly dispersed structure, smectite may form gels with rich microand macrocomposition that enables such sorbents with mucous cell protective abilities and lets them take part in the refreshing of microbiota, improvement of CT metabolism, stomach mucous membrane composition and function normalization. Smectite gel in the composition of Symbiter supplements the last with new physiological properties and considerably increases shelf life of the living probiotic preparation due to protective action on anaerobic bacteria. The gel has high adsorption abilities towards viruses, toxins, radionuclides, heavy metals and other harmful substances but it does not link bacterial cells between themselves and, accordingly, cannot disturb microbe balance in biotopes and lead to metabolic changes in the organism. When mixing cell biomass with smectite, the fine-dispersed sorbent binds with surface structures of bacterial cells, covers them and, therefore, protect from the inhibiting influence of stomach acid, pancreatic secretions, bile, lysozyme, enzymes, toxic radicals etc. This supports the probiotic biomass resistance in its passage through aggressive areas of intestinal tract [8]. The important features of the complex product synergetic activity are the smectite ability to strengthen the structure and quality of mucus matrix and the property of multicomponent symbiosis to normalize the composition and functions of indigenous physiological microbiota.

Of particular interest was the dynamics of transmembrane glycoproteins (mucins) structure at application of multiprobiotics.

\section{The objective of the research}

Increase of efficiency of CGD treatment in children with dysplasia of connective tissue through inclusion of complex multiprobiotic Symbiter ${ }^{\circledR}$ forte-M into the treatment scheme.

\section{Materials and methods}

There were examined 33 children from 11 to 17 years old with CHD against the background of DCT (the main group) and 32 healthy children similar in sex and ages (control). DCT diagnosis was verified based on external (clinical examination) and internal (laboratory, instrumental methods of examination) phenotypical signs. The results were presented according to the scores of Milkovska-Dimitrova in modification of L. N. Abakumova: whole scores up to 12 were considered as mild dysplasia (normal variant), 13-23 scores - moderate, and 24 scores and more - as clearly marked degree [9]. Children with moderate and marked degree of dysplasia were included in the main group. At CGD diagnostics, there were used all clinical and instrumental examinations (endoscopic and ultrasound) according to the protocol of the Ministry of Healthcare of Ukraine [1]. CGD diagnosis was confirmed by pathohistological study. To estimate mucous functions in GIT certain components of glycoproteins (fucose, sialic acids and glycolaminoglycans) were determined in mucous secretions of child organism before and after probiotic therapy. Local protective mechanisms were assessed by dynamics of antimicrobial peptides ( $\beta_{2}$-defencins), immunoglobulins and lysozyme.

Coprofiltrates (10\% solution) were prepared by faeces homogenization with physiological solution. The homogenate was centrifuged during $20 \mathrm{~min}(8000 \mathrm{rpm})$ in a cold centrifuge K-24 and then filtrated. Saliva $(2.0 \mathrm{ml})$ was collected on an empty stomach into a sterile tube during 10-15 min. Concentrations of glycolaminoglycans (GAG), sialic acids (SA), lysozyme, and general fucose in coprofiltrates (CF) were determined per $1 \mathrm{~g}$ of protein. Defencin (HBD-2ß) concentrations were estimated by immune-enzyme analysis with the use of ß-Defensin 2 ELITA Kit (Immundiagnostik $A G$, Germany).

At the initial stages treatment of the main group of children was performed during $2.3 \pm 1.5$ years according to the protocol of Ministry of Healthcare of Ukraine № 59, 29.01.2013 (data A). After the protocol therapy was finished, the multiprobiotic was prescribed according to the scheme - 1 sachet $\left(10 \mathrm{~cm}^{3}\right) 3$ times per 24 hours between food intakes, during 20 days with subsequent control examination (data B). Examinations before and after probiotic therapy were carried out in the non-active period of CGD and in the absence of other acute infectious or somatic pathologies. Statistical analysis of the categorical data in the form of adjustment tables $2 \times 2$ and quantitative data were performed with the use of $\mathrm{c}$-square criterion and T-criterion of Welch.

\section{Results and discussion}

Estimation of clinical symptoms before and after probiotic therapy showed significant index decreases of the abdominal pain syndrome from 23 to $13(P=0.03)$, dyspeptic symptoms from 30 to $22(P=0.04)$, and frequency and severity of CGD recurrences from 17 to $8(P=0.04)$. Simultaneously, there was observed improvement of emotional state (decrease of nervousness, lability, anxiety), increase of sleep duration, rise of physical activity and endurance, decrease of headache frequency and severity as a result of general non-specific intoxication decrease in these patients from 27 to $18(P=0.03)$. According to T-criterion of Welch with significance level $\alpha=0.05$ and $P=0.04$ differences in $\mathrm{BMI}$ were reliable $-14.8 \pm 2.6$ before and $16.7 \pm 2.2$ after treatment.

Mucins are expressed by intestine bacteria and form protective homeostatic barrier between residential microbiota and base intestinal immune cells. Due to mucins, mucous secretions acquire viscous, lubricating properties because glycosaminoglycans (GAG) bind high quantity of water and, as a result, they have gelatinous consistency. GAG and proteoglycans, as essential components of the intercellular matrix, play a substantial role in intercellular 
Table 1. Dynamics of some mucin constituents in coprofiltrates in children with CGD and DCT

\begin{tabular}{llll}
\hline Indices, unit & \multicolumn{2}{l}{ Main group, $\mathrm{n}=\mathbf{3 3}$} & Control group, $\mathrm{n}=\mathbf{3 2}$ \\
\cline { 2 - 3 } & $\mathbf{A}$ & $\mathbf{B}$ & \\
\hline GAG, $\mu \mathrm{M} / \mathrm{mg}$ & $1.07 \pm 0.09$ & $1.06 \pm 0.02$ & $1.06 \pm 0.03$ \\
Fucose $($ total), $\mu \mathrm{M} / \mathrm{mg}$ & $2.00 \pm 0.09$ & $(1.75 \pm 0.07)^{*}$ & $(0.98 \pm 0.08)^{* *}$ \\
Sialic acids, $\mu \mathrm{M} / \mathrm{mg}$ & $7.22 \pm 0.45$ & $(8.42 \pm 0.33)^{*}$ & $(16.95 \pm 0.85)^{* *}$ \\
\hline
\end{tabular}

$A$ : indices before probiotic therapy; $B$ : after probiotic therapy; ${ }^{*}$ : difference in $A$ and $B$ indices, $P \leq 0.05$;

${ }^{* *}$ : difference in $A$ and control indices, $P \leq 0.05$.

Table 2. Dynamics of ß-defencins in mucous secretions of children

\begin{tabular}{llll}
\hline Indices, unit & \multicolumn{2}{l}{ Main group, $\mathrm{n}=\mathbf{3 3}$} & \multirow{2}{*}{ Control group, $\mathrm{n}=\mathbf{3 2}$} \\
\cline { 2 - 3 } & A & B & \\
\hline HBD-2B in saliva, $\mathrm{ng} / \mathrm{ml}$ & $1.72 \pm 0.07$ & $(1.93 \pm 0.06)^{*}$ & $(2.64 \pm 0.09)^{* *}$ \\
HBD-2B in coprofiltrate, $\mathrm{ng} / \mathrm{ml}$ & $22.66 \pm 1.4$ & $(27.02 \pm 1.38)^{*}$ & $(31.03 \pm 1.85)^{* *}$ \\
\hline
\end{tabular}

$A$ : indices before probiotic therapy; $B$ : after probiotic therapy; *: difference in $A$ and $B$ indices, $P \leq 0.05$; **: difference in $A$ and control indices, $P \leq 0.05$.

Table 3. Dynamics of non-specific humoral factors of saliva and coprofiltrate local immunity

\begin{tabular}{|c|c|c|c|c|}
\hline \multirow[t]{2}{*}{ Indices, unit } & & \multicolumn{2}{|c|}{ Main group, $n=33$} & \multirow[t]{2}{*}{ Control group, $n=32$} \\
\hline & & A & B & \\
\hline \multirow[t]{4}{*}{ Saliva } & slgA, g/l & $0.52 \pm 0.052$ & $(0.41 \pm 0.02)^{*}$ & $(0.36 \pm 0.05)^{\star *}$ \\
\hline & $\lg A, g / 1$ & $0.03 \pm 0.01$ & $0.030 \pm 0.001$ & $0.040 \pm 0.001$ \\
\hline & $\lg G, g / l$ & $0.14 \pm 0.01$ & $0.15 \pm 0.01$ & $0.15 \pm 0.01$ \\
\hline & Lysozyme, $\mu \mathrm{g} / \mathrm{l}$ & $7.0 \pm 0.7$ & $(9.0 \pm 0.6)^{*}$ & $(10.0 \pm 0.9)^{\star \star}$ \\
\hline \multirow[t]{4}{*}{ Corpofiltrate } & slgA, g/l & $0.42 \pm 0.03$ & $(0.22 \pm 0.02)^{*}$ & $(0.18 \pm 0.01)^{\star *}$ \\
\hline & $\lg A, g / l$ & $0.020 \pm 0.002$ & $(0.030 \pm 0.003)^{*}$ & $(0.050 \pm 0.002)^{\star \star}$ \\
\hline & $\lg G, g / l$ & $0.070 \pm 0.004$ & $0.067 \pm 0.003$ & $(0.050 \pm 0.003)^{\star \star}$ \\
\hline & Lysozyme, $\mu \mathrm{g} / \mathrm{l}$ & $2.2 \pm 0.8$ & $(4.1 \pm 0.5)^{\star}$ & $(5.1 \pm 0.7)^{\star \star}$ \\
\hline
\end{tabular}

$A$ : indices before probiotic therapy; $B$ : after probiotic therapy; *: difference in $A$ and $B$ indices, $P \leq 0.05$; ${ }^{* *}$ : difference in $\mathrm{A}$ and control indices, $\mathrm{P} \leq 0.05$.

interactions, formation and maintaining of cells and organs shapes. Due to the specific structure and physico-chemical properties proteoglycans and glycosaminoglycans, as structural components of intercellular matrix, perform important functions in the human organism. They specifically interact with collagen, elastin, fibronectin, laminin and other proteins of the intercellular matrix; besides water, they may join large amounts of cations $\left(\mathrm{Na}^{+}, \mathrm{K}^{+}, \mathrm{Ca}^{2+}\right)$ and take part in different tissues turgor generation; they play the role of a molecular sieve in the intercellular matrix preventing pathogen microorganisms dissemination. Musins contain a large amount (up to $80 \%$ of the total mass) of O-bound oligosaccharides (O-glycans), which control antigenicity through interaction with surrounding, they bind with lectins, take part in the immune system regulation and, depending on structure, may be enabled in cell adhesion or, on the contrary, may have antiadhesive properties. They contain 1-20 carbohydrate residues, which form both linear and branched structures with fucose and sialic acid in terminal positions [10]. In fact, mucins are an endogenous source of carbohydrates that is necessary for microbiota maintaining.

The results of the study indicate that inflammatory processes in proximal GIT segments in children with DCT significantly influence some biochemical indices of MM: fucose concentration increases and sialic acids decreases (Table 1).

After the course of probiotic therapy, concentrations of fucose and sialic acids significantly changed according to T-criterion of Welch - these indices were near the ones in the control group: $p_{\text {fucose }}=0.03, p_{\text {sa }}=0.04(P \leq 0.05)$. We observed the tendency for fucose concentration to decrease and for SA to increase, whereas the GAG level did not change significantly $(P=0.91)$.

The data obtained indicate that MM chronic inflammatory process is characterized by high concentrations of fucose; its level decreases after probiotic therapy, which indirectly indicates destructive processes reduction. Many oligosaccharides, glycoproteins, and glycolipids contain fucose that, as compared with other carbohydrates, should have critical importance for the interaction with microbiota. Fucose gives not only energy for cells and forms nutritional medium for helpful intestinal microorganisms; it is a transient competitive inhibitor for pathogen lectins, lowering mucin loading with opportunity to normalize microbiota.

The concentration of sialic acid (SA), the most mobile component of mucin layer, decreases in gastroduodenal zone injury. SA level was most lowered in patients with erosive lesions of stomach, which indicated the destruction of mucous polymer structures and lowered synthesis of some mucous gel components. Significant increase of acidiferous SA concentration after probiotic therapy considerably differed from the indices at the beginning of the study $(P \leq 0.05)$; these indices were close to the ones of the control group, which indicated the increase of MM protective properties.

To detect the local protective system of mucous barrier changes before and after probiotic therapy, we estimated defencins, immunoglobulins, and lysozyme in CF and saliva; the indices were estimated according to T-criterion of Welch (Tables 2, 3).

Children with inflammatory GIT processes usually had increased levels of antimicrobial peptides, which is an indicator of non-specific protection. However, data given in Table 2, show significant reduction of HBD-2 $\beta$ in children's with CGD and DCT both saliva and coprofiltrates, comparing with healthy children $(P \leq 0.05)$. The results may indicate the innate deficiency of antimicrobial peptide synthesis or exhaustion of protective mechanisms of mucous secretions in these patients with chronic processes. Addition of multiprobiotics to the complex treatment led to increase in HBD-2ß level in both saliva and CF to $(1.93 \pm 0.06) \mathrm{ng} / \mathrm{ml}$ and $(27.02 \pm 1.38) \mathrm{ng} / \mathrm{ml}$, respectively; these indices were close to the control ones $\left(p_{\text {saliva }}=0.03, p_{C F}=0.03\right)$.

The results of the investigation of some saliva non-specific humoral immunity factors are given in the Table 3 . They indicate SIgA increase $(P=0.03)$ and rather low lysozyme level $(P=0.01)$ in these children as compared with the control group.

$\mathrm{CF}$ analysis of the local humoral immunity showed reduced $\lg A$ secretion $(P=0.0002)$ at increased SIgA values $(P=0.0001)$, which may indicate violent transformation of IgA into its secretory form in prolonged inflammatory process. Lysozyme concentration in saliva and CF was significantly reduced as compared with control $(P=0.01)$, which causes inability of GIT mucous membrane to resist the pathogens action and increases the risk of CGD relapses.

After multiprobiotic application, indices of the saliva and CF humoral immunity were close to the ones of healthy 
children. Marked tendency to indices normalization after probiotic therapy in both saliva $(P=0.01)$ and $C F(P=0.01)$ was observed for lysozyme, antimicrobial enzymes and bactericidal proteins of non-specific immune protection that may counteract the pathogen microorganisms adhesion to mucous membranes.

Our results suggest the normalization of effector functions of local protective mechanisms that may interfere with pathogenic microorganisms or eliminate them with normalization of gastrointestinal tract disturbed microbiocenosis.

Therefore, inflammation of GIT proximal parts in children is accompanied by qualitative and quantitative changes of mucous layer, which may influence the severity of pathological process and promote or prevent its recurrence. The obtained results show that an inflammatory process in the intestine of children with DCT leads to significant changes of MM biochemical indices: fucose concentration increases and SA level decreases. So, mucins, forming protective homeostatic barrier between residential microbiota and the base intestinal immune cells, have in their structure high quantity of fucose-containing glycoproteins and low concentration of sialic acids, substances that take part in the microbiota formation and are responsible for the reparative processes activity in the mucous membrane. Fucose-mediated interactions and microbiota damages play a considerable role in the mechanisms of intestinal inflammatory diseases and intercellular interactions.

Special category is children with CGD, associated with disorganization of CT. Deficiency of HBD-2ß defencin, local secretion of $\lg A$ and lysozyme results in decreasing in $\mathrm{MM}$ barrier properties, significantly decreases MM resistance to pathogenic microorganisms and may be a risk factor of the disease relapses.

The epithelial layer of intestinal cells endures large microbial load; it functions as an impermeable barrier for microorganisms and discriminates between pathogens and symbiont microbiota to maintain the state of low reactivity under conditions of continual high risk of microbes penetration. These processes are ensured by a specific immune system that is capable of restraining intestinal microbiota tissue invasion and maintaining symbiotic character of interaction with it, including the mucin fucosylation with lymphoid cells regulation.

Fucose-mediated interactions and microbiota disturbances play a significant role in the pathogenetic mechanisms of intestinal inflammatory processes. Fucose influences the expression of metabolic pathways and decreases the expression of bacterial virulence genes, as well as improves the organism tolerance to physiologic microbiota. Fast fucosylation is a protective mechanism that uses the macroorganism's resources to maintain interactions with microbes during pathogen-induced stress.

In 1965, for the first time, L. C. Hoskins at al. turned the attention on the link between fucose, $\mathrm{ABH}$ antigens, microbiota, mucins and diseases. Since then, the interest to this problem has been constantly kept up, and new findings bring us close to understanding the mechanisms of chronic inflammation development in all parts of GIT. The key fucose role in the interaction between macroorganism cells and its microbiota accounts for genetic susceptibility of patients with inactivated genes in FUT2 locus to development of chronic inflammatory processes in GIT.
Sooner or later, in such conditions, the balance between mucins production and their degradation should be disturbed (partly due to lowering of bacterial populations in the content of microbiota that synthesize such mucin stimulating metabolites as butyrate). Accordingly, prevalent symbionts might transfer to potentially harmful pathobionts, which may cause intestine inflammation. Musin degradation is connected not only with enzymes that remove terminal fucose; nevertheless, modern data indicate that fucose plays one of key roles (also through carbohydrate metabolism) in the normal microbiota formation. Inclusion of the multiprobiotic Symbiter ${ }^{\circledR}$ forte-M into the standard scheme of treatment ensured some components of mucous glycoproteins and factors of nonspecific humoral local immunity normalization. Due to the complex composition and inclusion of smectite gel, the multiprobiotic has the ability to high probiotic and immunomodulating properties; it improves cytoprotective and reparative characteristics of CGT mucous membrane and reduces the frequency of severe destructive processes in children with DCT at the background of CGD.

\section{Conclusions}

1. At development of CGD in children with DCT, mucins, forming protective homeostatic barrier between residential microbiota and base intestinal immune cells, contain increased quantity of fucose-containing glycoproteins in their structure and low level of sialic acids. This influences the features of microbiota formation and activity of cytoprotective and reparative processes in MM.

2. Inclusion of the multiprobiotic Symbiter ${ }^{\circledR}$ forte-M into the standard scheme of treatment ensured some components of mucous glycoproteins and factors of nonspecific humoral local immunity normalization. Due to the complex composition and inclusion of natural mineral gel (smectite) the multiprobiotic has high probiotic and immunomodulating properties; accordingly, it improves cytoprotective and reparative characteristics of CGT mucous membrane and reduces the frequency of severe destructive processes in children with CGD and DCT.

\section{References}

[1] Nakaz MOZ Ukrainy «Pro zatverzhennia unifikovanykh protokoliv medychnoi dopomohy ditiam iz zakhvoriuvanniamy orhaniv travlennias vid 29.01.2013 roku №59 [Order of Ministry of Health 'Defining unified protocols of medical assistance to children with digestive system diseases' from January 29, 2013, №59]. Retrieved from http://www. moz.gov.ua. [in Ukrainian].

[2] Kondrashova, V. H., Kolpakov, I. Ye., Vdovenko, V. Yu., Hrytsenko, T. V., Shepeliuk, T. V., Studenikina, O. N., \& Stepanova, Ye. I. (2014) Kliniko-anamnestychni osoblyvosti patolohii shlunkovo-kyshkovoho traktu u ditej iz syndromom dysplazii spoluchnoi tkanyny sertsia, yaki narodylysia vid batkiv, oprominenykh u dytiachomu vici v rezultati avarii na CHAES [Clinical and anamnestic features of pathology of gastrointestinal tract in children with syndrome of heart connective tissue dysplasia, born to parents irradiated in childhood due to the Chernobyl accident]. Zdorov'e rebenka, 6, 57-60. [in Ukrainian].

[3] Mukvich, O. M., Lavrenchuk, O. V., Gridina, T. A., \& Poluk, T. A. (2015) Osoblyvosti klinichnoho perebihu khronichnoho hastroduodenitu u ditei $z$ dysplazieiu spoluchnoi tkanyny [Clinical picture of chronic gastroduodenitis in children with connective tissue dysplasia]. Perinatolohiya i pediatriya, 1(61), 81-86. [in Ukrainian]. doi: 10.15574/PP.2015.61.81.

[4] Shpagin, V. A (2015) Dejstvie selena na immunitet i antioksidantnuyu zashchitu u detej s khronicheskim gastroduodenitom [The impact of selenium on the immune system and antioxidant defense of children with deep-rooted gastroduodenitis]. MEDICUS, 4(4), 59-61. [in Russian].

[5] Bengmark, S. (2012) Gut microbiota, immune development and function. Pharmacol. Res., 69(1), 87-113. doi: 10.1016/j.phrs.2012.09.002. 
[6] Duary, R. K., Bhausaheb, M. A., Batish, V. K., \& Grover, S. (2012). Anti-inflammatory and immunomodulatory efficacy of indigenous probiotic Lactobacillus plantarum Lp91 in colitis mouse model. Mol. Biol. Rep., 39(4), 4765-4775. doi: 10.1007/s11033-011-1269-1.

[7] Khamagaeva, I. S. (2014) Perspektivy ispol'zovaniya probioticheskikh mikroorganizmov v sovremennoj biotekhnologii [Prospects for the use of probiotic microorganisms in modern biotechnology]. Vestnik VSGUTU, 5(50), 111-116. [in Russian].

[8] Shyrobokov, V. P., Yankovsky, D. S., \& Dyment, H. S. (2014) Mikrobiom liudyny ta suchasni metody yoho ozdorovlennia [Human microbiom and modern methods of its sanitation]. Infektsiini khvoroby, 2, 64-69. [in Ukrainian].

[9] Abbakumova, L. N. (2006) Displaziya soiedinitiel'noj tkani [Connective tissue dysplasia]. Saint Petersburg. [in Russian].

[10] Makarova, S. G (2013) Prebiotiki kak funkcional'nyj component pitaniya rebenka [Prebiotics as a «Functional» Component of Child Nutrition]. Voprosy sovremennoj pediatrii, 12(5), 8-17. [in Russian].

\section{Information about authors:}

Mukvich O. M., MD, PhD, DSc, Senior Scientific Researcher, Institute of Pediatrics, Obstetrics and Gynecology of NAMS Ukraine, Kyiv.

Yankovskyi D. S., PhD, DSc in Biology, Professor, CEO of Scientific Production Company "O. D. Prolisok”, Kyiv, Ukraine.

Shyrobokov V. P., MD, PhD, DSc, Professor, Academician of NAN and NAMS of Ukraine, Head of the Department of Microbiology, Virusology and Immunology, 0. 0. Bogomolets National Medical University, Kyiv, Ukraine.

Dyment, H. S., PhD in Technical Sciences, Director of Scientific

Production Company “O. D. Prolisok”, Kyiv, Ukraine.

Lavrenchuk O. V., MD, District Doctor, Public Non-Profit

Enterprise "Center of Primary Medical and Sanitary Health № 1", Shevchenko District, Kyiv, Ukraine.

\section{Відомості про авторів:}

Муквіч О. М., А-р меА. наук, головний науковий співробітник, АУ "Інститут педіатрії, акушерства і гінекології НАМН України", м. Київ.

Янковський А. С., А-р біол. наук, проф., генеральний Аиректор НВК "О.А. Пролісок", м. Київ, Україна.

Широбоков В. П., А-р меА. наук, професор, акаА. НАН України, акаА. НАМН України, зав. каф. мікробіології, вірусології та імунології, Національний меАичний університет імені О. О. Богомольця, м. Київ, Україна.

Аимент Г. С., канА. тех. наук, Аиректор наукового центру НВК "О.А. Пролісок", м. Київ, Україна.

Аавренчук О. В., Аільничний мікар, КНП “ЦПМСА № 1" Шевченківського району м. Києва, Україна.

\section{Сведения об авторах:}

Муквич Е. Н., А-р меА. наук, главный научный сотрудник, ГУ "Институт педиатрии, акушерства и гинекологии НАМН Украины", г. Киев.

Янковский А. С., А-р биол. наук, профессор, генеральный Аиректор НПК "О.А. Пролісок", г. Киев, Украина.

Широбоков В. П., А-р меА. наук, профессор, акаА. НАН Украины, акаА. НАМН Украины, зав. каф. микробиологии, вирусологии и иммунологии, Национальный медицинский университет имени А. А. Богомольца, г. Киев, Украина.

Аымент Г. С., канА. тех. наук, Аиректор научного центра

НПК "О.А Пролісок", г. Киев, Украина.

^авренчук О. В., участковый пеАиатр, КНП “ЦПМСП № 1"

Шевченковского района г. Киева, Украина.

Conflicts of Interest: authors have no conflict of interest to declare. Конфлікт інтересів: віАсутній. 